\title{
A NAGYVÁLLALATI ÖNKÉNTESSÉG AZ ELMÚLT TíZ ÉVBEN - AZ EFFEKTEAM VIZSGÁLATAINAK TÜKRÉBEN
}

DOI: https://doi.org/10.53585/OnkSzem.2021.4.102-122

\section{Absztrakt}

Magyarországon a nagyvállalatoknál jellemzően a kétezres évek közepén jelentek meg az első önkéntes aktivitások, amelyek többnyire alulról jövő kollegiális, jótékony összefogások formájában, szabadidőben valósultak meg. Az önkéntes keretek, policyk kialakítása, valamint a vállalatok részéról kezdeményezett programok ösztönzése, szervezése inkább a kétezres évek második felében kapott teret a vállalatok társadalmi felelősségvállalási gyakorlatában. Ez összefügg azzal, hogy maga a nagyvállalati társadalmi felelősségvállalás - vagy, ahogy akkoriban a vállalatok és a szakma is nevezte CSR - a kétezres évek közepén bontakozott ki erőteljesen és szilárdult meg a nagyvállalati kultúrában. Ennek következtében a hazai nagyvállalati önkéntesség első fejlődési szakasza az elmúlt 10 évre tehető, ezt az időszakot vizsgáljuk meg az elemzésben.

A tanulmányban bemutatjuk, hogyan változott hazánkban a nagyvállalati önkéntesség az elmúlt 10 évben. Elemeire, illetve mutatóira bontjuk az önkéntesség gyakorlatát és egy áttekintő képet formálunk a tervezés, menedzselés, utánkövetés megvalósításáról. Ezenfelül bemutatjuk azokat a tényezőket, amelyek hatást gyakorolhattak, illetve befolyásolhatták a hazai nagyvállalati önkéntesség alakulását.

Kulcsszavak: CSR, társadalmi felelősségvállalás, felelős vállalatok, vállalati önkéntesség

\section{The practice of corporate volunteering in light of the past 10 years - in context of}

\section{Effecteam's studies}

\section{Klára Molnár}

\section{Abstract}

In Hungary, the first volunteer activities in large companies appeared in the mid-2000s and were executed characteristically with a bottom-up approach, in the form of collegial charity cooperation, as free-time activities. The establishment of the frameworks and policies of volunteering, as well as the promotion and organization of corporate-initiated programmes gained importance in the practice of corporate social responsibility in the second half of the 2000s. This is related to the fact that corporate social responsibility itself - called CSR by the companies and professionals as well back then in Hungary - emerged strongly and became firmly established in the corporate culture in the mid-2000s. Therefore, the first development phase of corporate volunteering in Hungary can be dated back to the last ten years. This period will be examined by this analysis.

\footnotetext{
${ }^{1}$ Molnár Klára (univ. doc. jur) jogász, igazgató, szakmai vezető Effekteam Egyesület
} 
In this study, we aim to demonstrate how corporate volunteering has changed in Hungary over the last 10 years, in the light of the Effecteam's research. We break down the practice of volunteering into its elements and indicators, and present an overview of how it is planned, managed and followed up. Furthermore, we present the factors that might have influenced the evolution of corporate volunteering in Hungary.

Keywords: CSR, corporate social responsibility, responsible companies, corporate volunteering

\section{BEVEZETÉS}

A vállalati önkéntesség szerves része egy cég társadalmi felelősségvállalásának, melynek során a vállalat munkatársai munkaidőben vagy szabadidejükben valami fontos, értelemteli cselekvést hajtanak végre azzal a céllal, hogy hozzájáruljanak a társadalom, a közösség, és az egyes emberek jóllétéhez, kiemelten abban a közösségben, melyben a cég múködik. Ezáltal a vállalat - lehetőségeihez mérten - erőforrásai egy részét visszaadja a társadalom számára, miközben a munkatársaknak is megvan a lehetőségük az önkéntes projektekben való részvételre, hogy élményekkel, ismeretekkel, képességekkel stb. gazdagodjanak. Sőt mindezeken túl a vállalat üzleti múködésére - üzletmenet, reputáció, fogyasztói kapcsolatok stb. - is pozitív hatással lehet a jól tervezett és menedzselt önkénteskedés.

A tanulmányban bemutatjuk és elemezzük a hazai vállalati önkéntesség főbb jellemzőit, például, hogy ez a fajta támogatási forma mennyiben kapott szerepet, hangsúlyt az évek során a többi támogatási formához képest. Továbbá, arra a kérdésre keressük a választ, hogy vajon miért vágnak bele a cégek az ilyen típusú aktivitásokba, hogy mennyire proaktívak ezen a téren és ki felel a cégen belül az önkéntesség szervezéséért. Fontosnak tartjuk megvizsgálni a vállalati önkéntesség főbb mutatóit: a vállalati munkatársaknak munkaidőben vagy szabadidőben van lehetőségük másokon segíteni; ez egyéni vagy csoportos formában valósule meg; illetve, inkább fizikai vagy szellemi és/vagy pro bono segítségnyújtás történik-e a részükről. A tanulmány végén kitérünk a vállalati önkéntesség által elérhető eredményekre és hatásokra is.

Az elemzéshez szolgáló kereteket az Effekteam Egyesület (korábbi néven: Magyar Adományozói Fórum) által végzett kutatási anyagok biztosították. Az Effekteam Egyesület kutatásai az aktuális TOP 200 vállalatot (Figyelő éves listái, nettó árbevétel alapján), TOP 20 bankintézményt (Figyelő éves listái, mérlegfőösszeg és eredmény alapján), valamint a TOP 10 biztosítót (Figyelő éves listái, díjbevételek alapján) vonták be a mintába. A különböző listák alapján készült elemzéseink 2011-2013 között, illetve 2015 és 2016-ban, valamint 2021-ben 
készültek, és megállapításainkat ezen adatok alapján fogalmazzuk meg a nagyvállalati szektorra.

A felmérések során rendszerint 50 körüli válaszadó került be a vizsgálati mintába. Bár ez az adat nem túnik számottevőnek, azonban érdemes figyelembe venni azt, hogy a mintában szereplő cégek közel fele nem végzett a vizsgálat időpontjában társadalmi felelősségvállalással kapcsolatos aktivitásokat. A cégek további, jelentős hányadánál pedig nagyon kezdetleges, ad hoc módon megvalósuló kezdeményezések voltak jelen. Így tehát, az Effekteam - 2011-2013 között, illetve 2015 és 2016-ban készült - elemzései alapján azt mondhatjuk, hogy az elmúlt 10 évben körülbelül minden negyedik, illetve ötödik nagyvállalatnál volt fellelhető valamilyen formában a vállalati önkéntesség.

Mindezen kutatások megléte ellenére fontos kiemelni, hogy a hazai vállalati önkéntesség vizsgálata a mai napig feltáratlan terület, nem állnak rendelkezésre rendszeres és a teljes vállalati szektort lefedő kutatások, elemzések. Így a rendelkezésre álló információk részlegesek - ahogy fent is említésre került - jelen tanulmány esetén a vállalati szektor egy szeletére irányulnak.

\section{AZ ÖNKÉNTESSÉG ARÁNYA, SZEREPE ÉS TÉRNYERÉSE A TÁRSADALMI BEFEKTETÉSEK TERÉN}

Társadalmi befektetéseknek nevezzük azokat a vállalati forrásokat, melyeket a cégek önként, a saját erőforrásaikból biztosítanak olyan társadalmi, környezeti ügyek vagy szervezetek támogatásához, melyeknek közérdekű vagy közcél jellegük van.

\section{Társadalmi befektetések mint erőforrások}

Társadalmi befektetéseknek nevezzük azokat a vállalati forrásokat, melyeket a cégek önként, a saját erőforrásaikból biztosítanak olyan társadalmi, környezeti ügyek vagy szervezetek támogatásához, melyeknek közérdekű vagy közcél jellegük van.

\section{A társadalmi befektetések mint eröforrások}

A társadalmi befektetéseknek többféle szegmentációja létezik. Ezek egyike, amikor a társadalmi befektetéseket mint vállalati erőforrásokat definiáljuk. Ezen szegmentáció mentén beszélhetünk:

(1) pénzbeni támogatásokról; 
(2) természetbeni támogatásokról;

(3) a munkavállalók munkaidejéről, azaz vállalati önkéntességről.

Az elmúlt 10 évben az Effekteam 2012-ben és 2016-ban vizsgálta ezen erőforrások egymáshoz viszonyított arányát. Az akkori eredmények azt mutatták, hogy a 2010-es évek elején az önkéntesség aránya jóval a pénzbeni és a természetbeni támogatások mögött foglalt helyet. 2012-ben a vállalatok 1-5-ig terjedő skálán 2,5-re értékelték azt, hogy cégüknél mennyire jellemző az önkéntesség. Ezzel szemben a pénzbeni támogatások 3,76-os, a természetbeni támogatások pedig 3,12-es értéket kaptak (Effekteam Egyesület 2012:7).

Az idő előrehaladtával az arányok változtak, és az önkéntesség már nagyobb hányadot tett ki az erőforrások tortájából. 2016-ban megerősítést kaptunk egy folyamatosan növekvő tendenciára, hiszen összehasonlítva a 2012-es adatokkal, szemmel látható, hogy a vállalati önkéntesség részaránya dinamikus fejlődésnek indult. Míg 2012-ben a vállalatok fele nyilatkozott úgy, hogy engedi a munkatársak számára az önkéntes munkát, 2016-ban közel háromnegyedük jelezte ezt (1. ábra).

1. ábra A támogatási program során felhasznált erőforrások

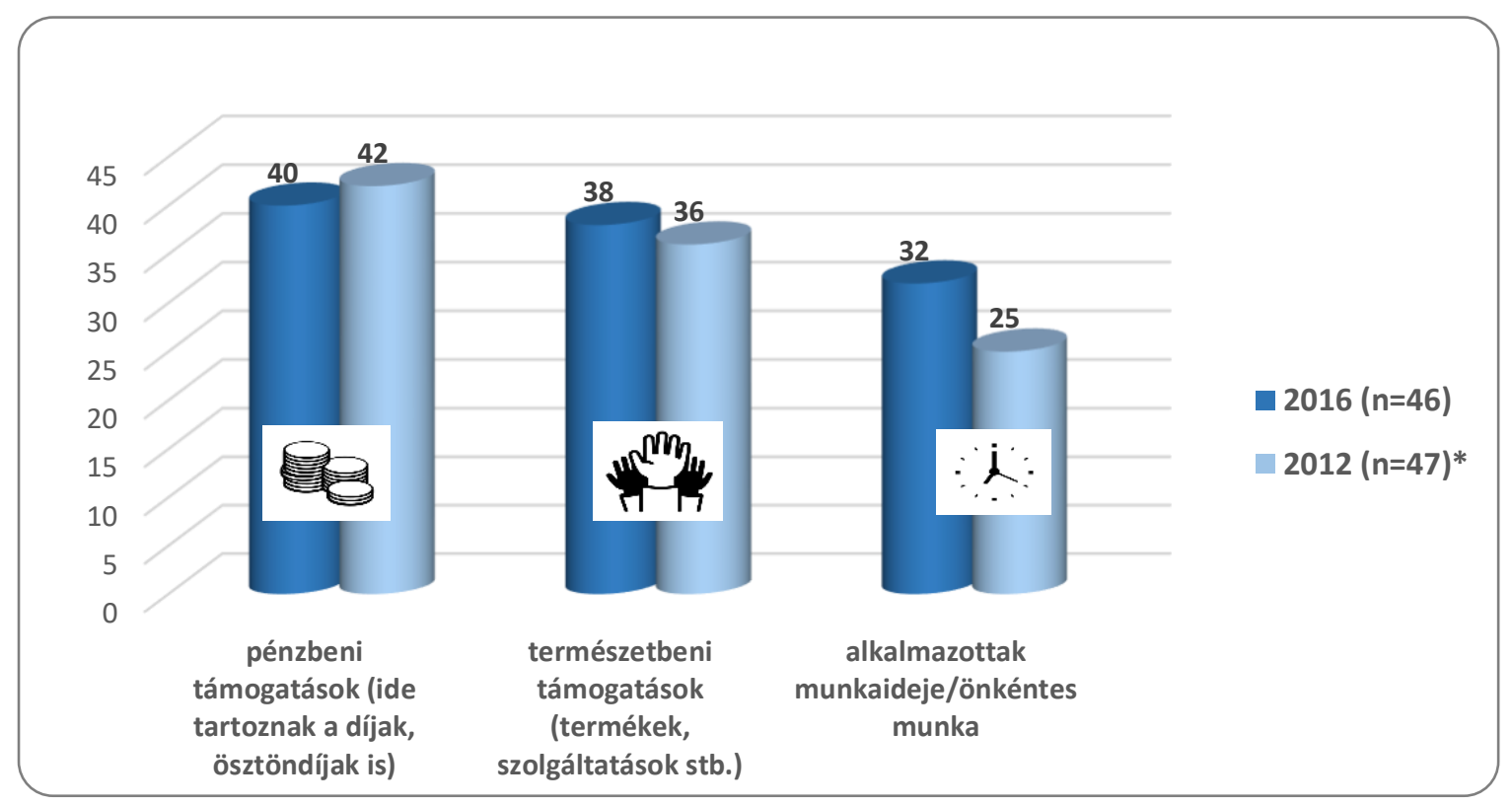

Forrás: Az Effekteam Egyesület 2016-os kutatása 5.oldal

Az Effekteam 2013-as kutatása arra szolgáltatott eredményeket, hogy az alkalmazottak munkaidejének vállalati önkéntes programokba való irányítása növekedett a 2009-2012 közötti években, hiszen a cégek 58 százaléka jelezte, hogy munkavállalói többet időt töltenek 
önkéntes munkával, mint a korábbi években. Maguk a cégek is azt prognosztizálták, hogy döntő többségüknél nőni fog a munkavállalói önkéntesség a következő két évben (Effekteam Egyesület 2013:11). A változásokat leginkább a bevont alkalmazottak létszámában és az általuk kezdeményezett aktivitások arányában valószínűsítették. Az előbbit a cégek körülbelül 60 százaléka jelezte előre, míg az önkéntességre biztosított munkaidő növekedését 42 százalékuk (Effekteam Egyesület 2013:13).

Az Effekteam 2015-ös felmérése alapján azt találtuk, hogy a növekedés nem alakult a prognózisnak megfelelő mértékben, hiszen csak a vállalatok 41 százalékánál nőtt a bevont munkatársak száma, továbbá az önkéntesség megvalósításához biztosított munkaóráké pedig csak 26 százalékos volt (Effekteam Egyesület 2015:20). Ennek okait a jövőben érdemes lenne megvizsgálni, hiszen a területen történő előrelépéshez szükséges lenne látni, hogy milyen okok álltak a történések hátterében.

A 2015-ös felmérésben ugyancsak arra kértük a vállalatokat, hogy prognosztizálják a következő három évre vonatkozóan a vállalati önkéntesség mutatóit. A 2000-es évek második felére tett előrejelzések szerint leginkább az önkéntesek létszámának (a cégek 57 százaléka nyilatkozta) növekedését jelezték előre, míg az eltöltött munkaórák emelkedését csak a vállalatok 38 százaléka jelezte előre (Effekteam Egyesület 2015:21). Az Effekteam vállalati munkacsoport találkozóin született beszélgetések, és a 2021-es kismintás felvételnek eredménye alapján azt mondhatjuk, hogy ezek az előrejelzések - ha nem is ilyen mértékben , de reálisnak mutatkoztak.

A vállalati önkéntesség térnyerésének dinamikája egészen a koronavírus-járványig intenzívnek volt mondható. Ezt jól visszaadja az Effekteam 2021-ben készült kismintás (15 vállalatra kiterjedő) felvétele, amelyből kiderül, hogy a pandémiás éveket megelőzően a vizsgált vállalatok felénél a fizikai önkéntesség mértéke egyértelműen növekedett (Effekteam Egyesület 2021:7). Ugyanakkor 2020-ban a járvány kitörésével a fizikai önkéntesség szinte teljességgel ellehetetlenült. A későbbiekben látni fogjuk, hogy a szellemi/szakmai önkéntesség még nem volt annyira elterjedt és beágyazott a vállalati gyakorlatokban, hogy át tudta volna venni a fizikai önkéntesség helyét.

\section{Társadalmi befektetések mint támogatási formák}

A vállalati társadalmi befektetések egy másik szegmentációja szerint a támogatási formákat tekintve megkülönböztethetünk: 
(1) hosszú távú partnerségeket;

(2) önkéntes programokat;

(3) pályázati támogatásokat;

(4) eseti vagy ad-hoc támogatásokat.

Ezen osztályozás szerint a hazai vállalatok számára a hosszú távú partnerségek foglalták el az elmúlt 10 évben az első helyet. Az Effekteam 2016-os kutatásának adatai (2. ábra) azt mutatják, hogy a társadalmi befektetések ezen csoportosítása szerint az önkéntesség a 2010es évek közepére - a partnerségek és együttműködések után - az előkelő második helyre került.

2. ábra Melyik forma jellemző leginkább vállalatuk támogatási programjaira? (a válaszok százalékában)

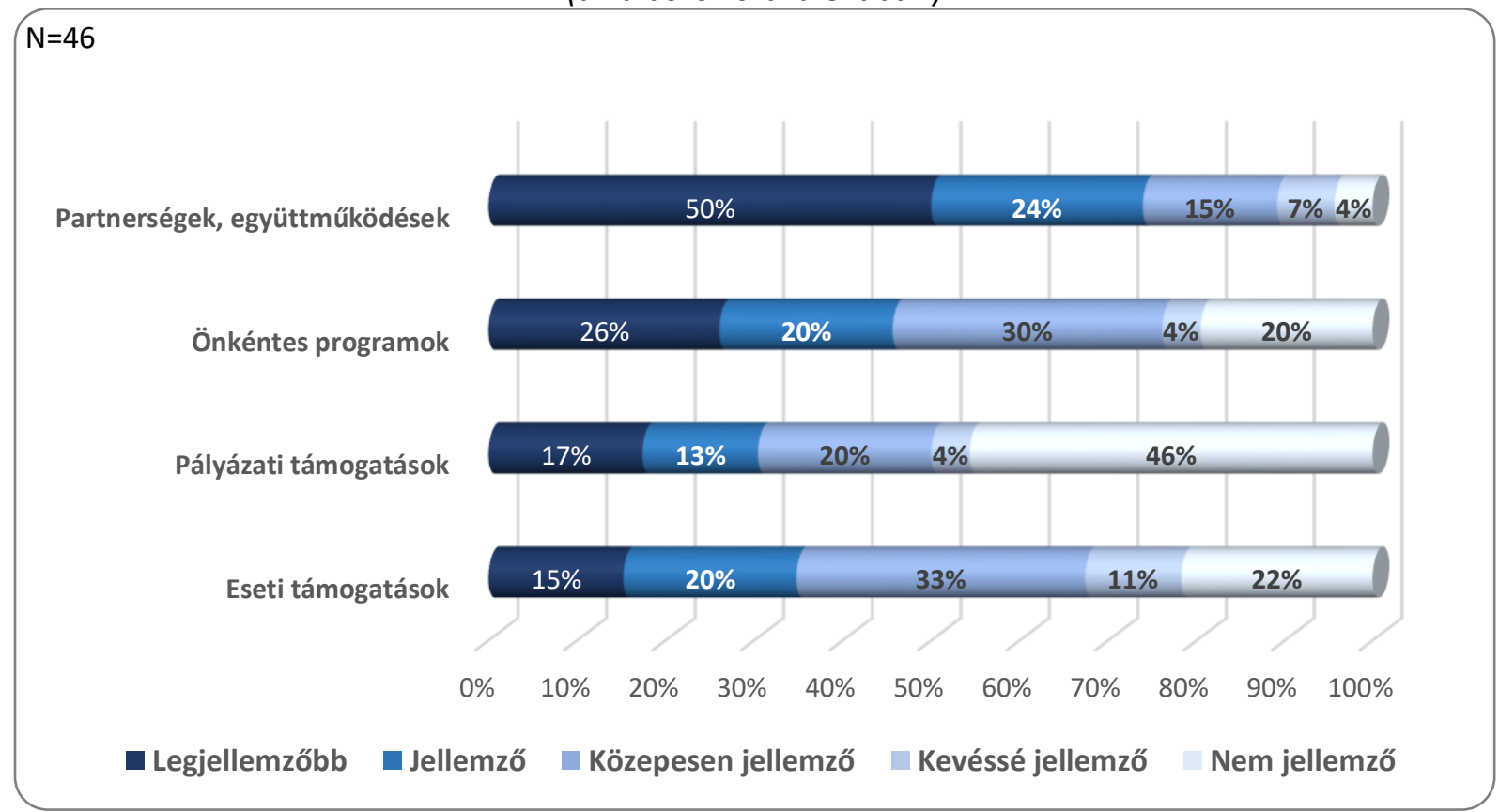

Forrás: Az Effekteam Egyesület 2016-os kutatása 13.oldal

Ma már elmondható, a 2021-es felvétel adatai alapján, hogy az önkéntes programokat megelőzi a pályázati támogatások preferálása (Effekteam Egyesület 2021:9). Ezen változásnak a hátterében úgy véljük, egyfelől a nemzetközi anyavállalatok gyakorlatának átvétele, másfelől a vállalatok körében ezen időszak alatt nyert teret a hatékony pályázati rendszer bevezetése. 


\section{A VÁLLALATI ÖNKÉNTESSÉG CÉLJAI}

Alapvető kérdésként merülhet fel, miért is kínálják fel a vállalatok azt a lehetőséget, hogy a munkatársak önkéntes programokban vegyenek részt? Az Effekteam elemzései jól reprezentálják, hogy a 2000-es évek elején, illetve közepén mennyiben változott a vállalatok szemlélete ennek a kérdésnek a tükrében. A 2011-es felmérés szerint a megkérdezett 34 vállalat leginkább azt várta az önkéntességtől, hogy a csapategység is fejlődik, nő a vállalati reputáció, javul a munkavállalók elégedettsége, valamint nő a munkatársak lojalitása a vállalathoz (3. ábra).

3. ábra Mely vállalati célok játszanak szerepet az önkéntes munka támogatásában, szervezésében? (a válaszadó vállalatok számában)

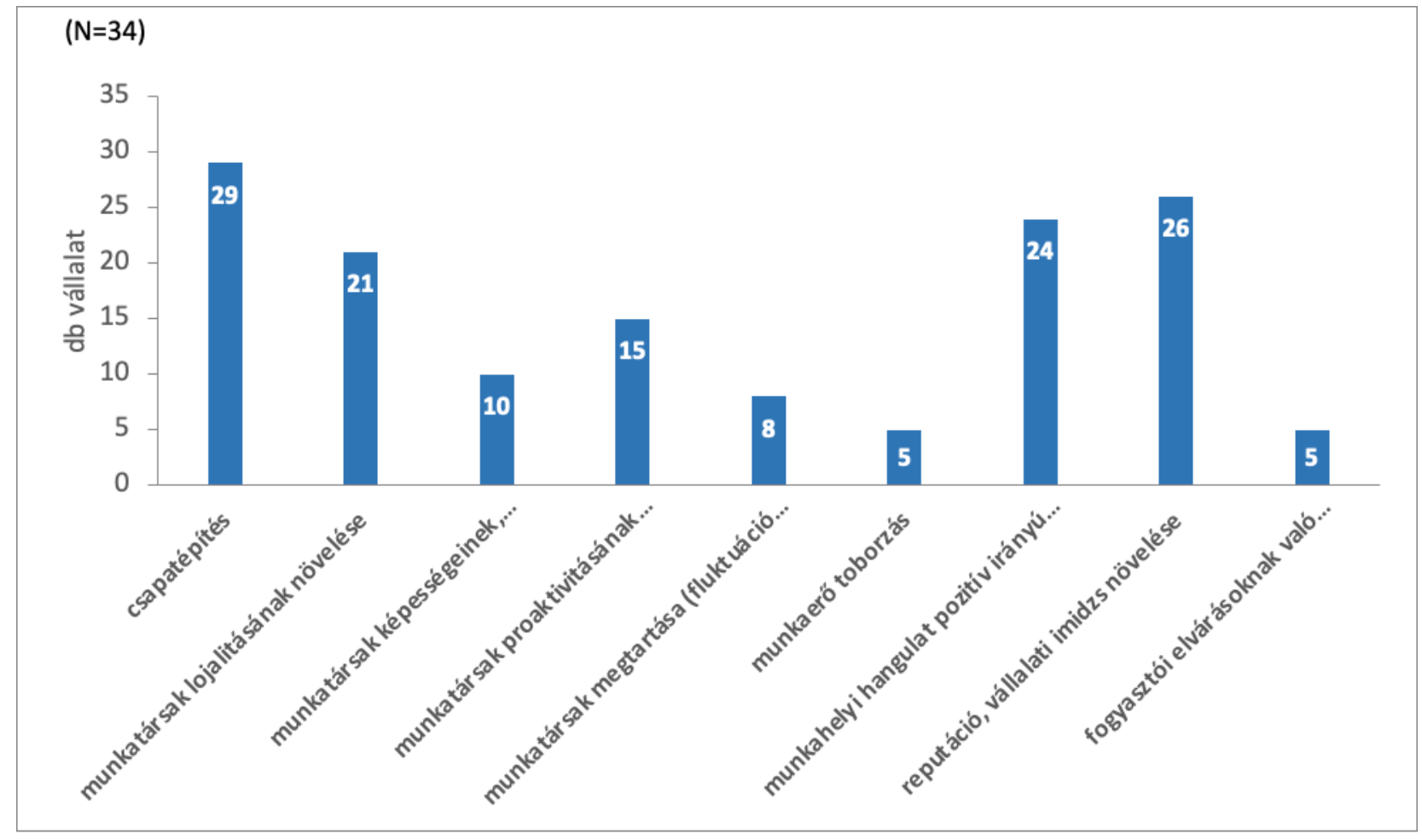

Forrás: Az Effekteam Egyesület 2011-es kutatása 7.oldal

A némiképp eltérő kérdéssor mentén készült 2015-ös felmérés adatai azonban már azt mutatták, hogy a megkérdezett cégek leginkább azt várták az önkéntességtől, hogy nő a vállalat iránti elkötelezettség (4. ábra). Ezt követte a munkahelyi hangulat elégedettségének javítása, valamint ugyanilyen erősséggel a csapatépítés, együttműködési készségek fejlesztésének célja. Kiemelkedik még ebből a rangsorból a negyedik legtöbbet említett cél: a munkavállalók érzékenyítése, nyitottságának ösztönzése az önkéntes munkavégzésre. A 
megjelölt célok középmezőnyében foglaltak helyet az olyan választások mint: a reputáció javítása a külső érintettek körében, a munkatársak lojalitása, megtartása, valamint a dolgozók bevonódásának javítása.

4. ábra Milyen vállalati célok játszanak szerepet Önöknél a munkatársak önkéntességbe való bevonásakor? (a válaszadó vállalatok számában)

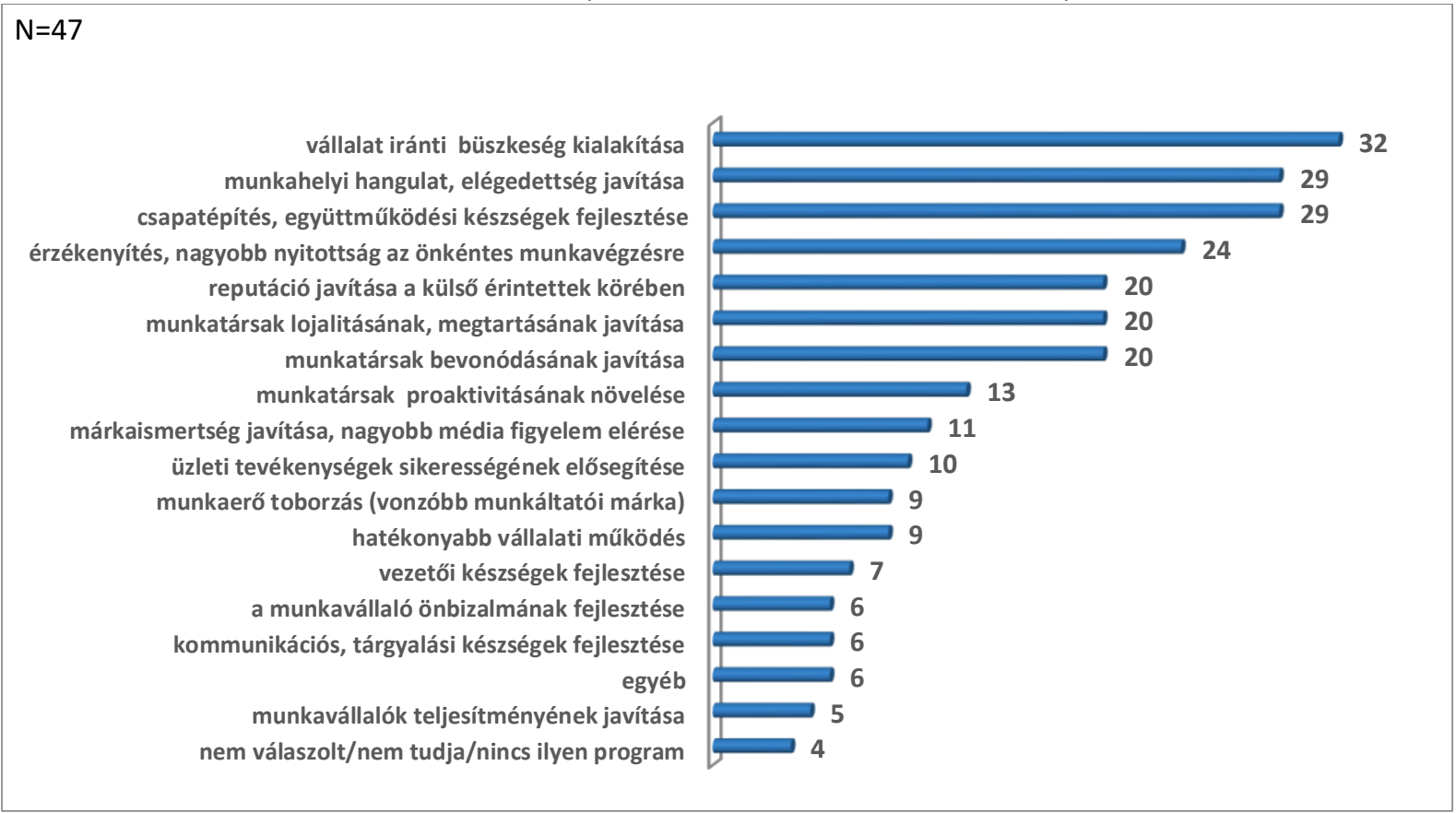

Forrás: Az Effekteam Egyesület 2015-ös kutatása 8.oldal

Ezen célok megfogalmazását és elérését segíti az is, - ahogy a következő fejezetekben látni fogjuk -, hogy a vállalatok nagy részénél az önkéntesség, de a felelősségvállalás tervezésében és szervezésében nagy szerep jut a vállalati kommunikációs, PR-os, marketinges munkatársaknak. Felméréseinkből egyértelmúen kiderült az is, hogy az önkéntesek képességés készségfejlesztése mint cél (például a személyes, menedzsment és az üzleti hatékonyság) melyre a vállalati önkéntesség szintén lehetőséget adna -, a cégek számára a fentiekben felsorolt szempontokhoz képest inkább másodlagosként jelent meg.

\section{VÁLLALATON BELÜLI FELELŐSÖK}

Fontos kérdés, hogy cégen belül ki a felelős az önkéntes programok múködéséért. $A z$ Effekteam kutatásai azt mutatják, hogy a vállalatoknál ez a terület egyre inkább eltolódott a HR és a kommunikációs részleg közös munkája felé. A két szervezet megjelenését az 
önkéntesség koordinálásában 2011-ben még csak a megkérdezett vállalatok 31 százaléka jelezte, de több volt az olyan cégek aránya (36 százalék), ahol még változó jelleggel dedikáltak felelőst a témának (Effekteam Egyesület 2011:6). Viszont a 2015-ös adatok szerint a megkérdezett vállalatok 38 százalékánál már a két osztály részvételével szervezték az önkéntességet (5. ábra).

5. ábra Ki felelös a vállalatnál a munkatársak önkéntes munkájának tervezéséért, szervezéséért? (a válaszadó vállalatok számában)

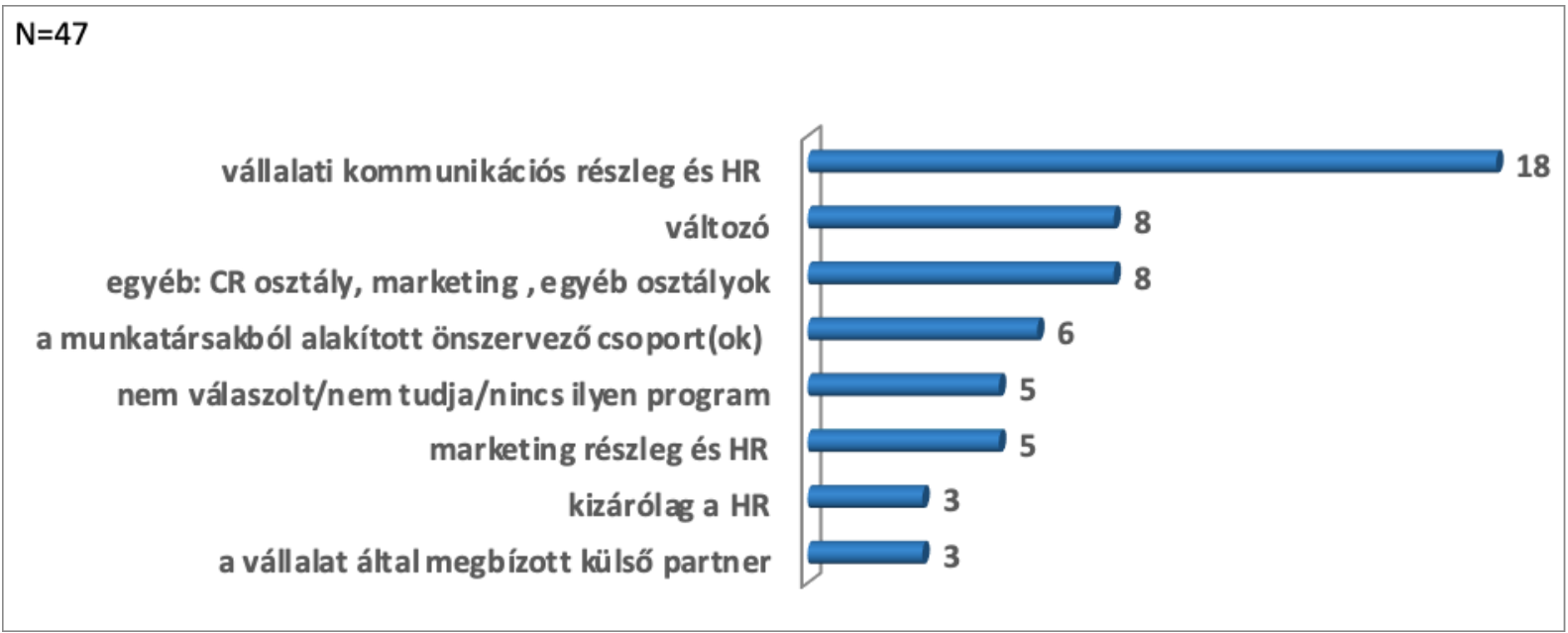

Forrás: Az Effekteam Egyesület 2015-ös kutatása 12.oldal

A fenti adatokban azonban nincs semmi meglepő, ha figyelembe vesszük azt, hogy idehaza a társadalmi felelősségvállalás menedzselése a 2000-es években leginkább a PR és kommunikációs osztályokhoz volt köthető, amit 2016-os kutatásunk is visszaigazolt.

\section{A VÁLLALATI SZEREPVÁLLALÁS}

Vajon proaktívan vagy reaktívan állnak hozzá a cégek az önkéntesség megvalósításához? A vállalatok nagy részénél több lehetőség is rendelkezésre állt az elmúlt 10 évben a munkatársak számára, hogy önkéntes tevékenységekben vehessenek részt.

Egyrészt a vállalatok többsége úgynevezett központi önkéntes eseményeket szervez, amelyre erősen ösztönzi a dolgozók részvételét. Ezen felül sok cég inspirálja munkavállalóit arra, hogy maguk is keressenek olyan szervezeteket, ahol szívesen segítenének. Ez utóbbi lehetőséget van, hogy ad hoc módon kezeli a cég - vagyis a munkatársak egyéni kéréseit az év során folyamatosan értékeli -, de több helyen pályázati rendszert is kialakítottak arra, hogy a 
kollegák igényeit a megfelelő helyre tudják becsatornázni. Ilyen esetben évente egy vagy két alkalommal, de akár folyamatosan is lehetőségük van a dolgozóknak ún. belsős pályázatot benyújtani, amit a vállalat szakértői bizottsága értékel, és támogatásban részesíti vagy elutasítja a kérést. Elutasításra - jellemzően - a vállalat társadalmi felelősségvállalási koncepciójától távol álló opciók esetén kerül sor.

Összességében azt mondhatjuk, hogy a vállalatok hozzáállása az önkéntességhez az elmúlt 10 évet tekintve inkább proaktív, mint reaktív volt. Egyrészt keresték és szervezték maguk is az alkalmakat, ahol a munkatársak mások segítségére lehettek, másrészt ösztönözték is a kollegáikat arra, hogy ők maguk is szervezzenek ilyen eseményeket, amelyeket a vállalatok többsége anyagi erőforrással is támogatni tudott. 2011-ben a vállalatok 66 százaléka jelezte, hogy a cég proaktívan keresi az önkéntes munka formájában megvalósuló támogatási lehetőségeket (Effekteam Egyesület 2011:5).

Az Effekteam 2015-ben végzett kutatása szerint a vállalati önkéntesség szervezésében a megkérdezettek nagy hányada maga is kezdeményező volt, míg a dolgozók kezdeményező készsége alacsonyabban, kis mértékben volt jelen (6. ábra).

6. ábra Kinek a kezdeményezésére, illetve szabadidőben vagy munkaidőben szervezett önkéntes programokban vehetnek részt a munkavállalók a vállalatuknál?

(a válaszadó vállalatok számában)

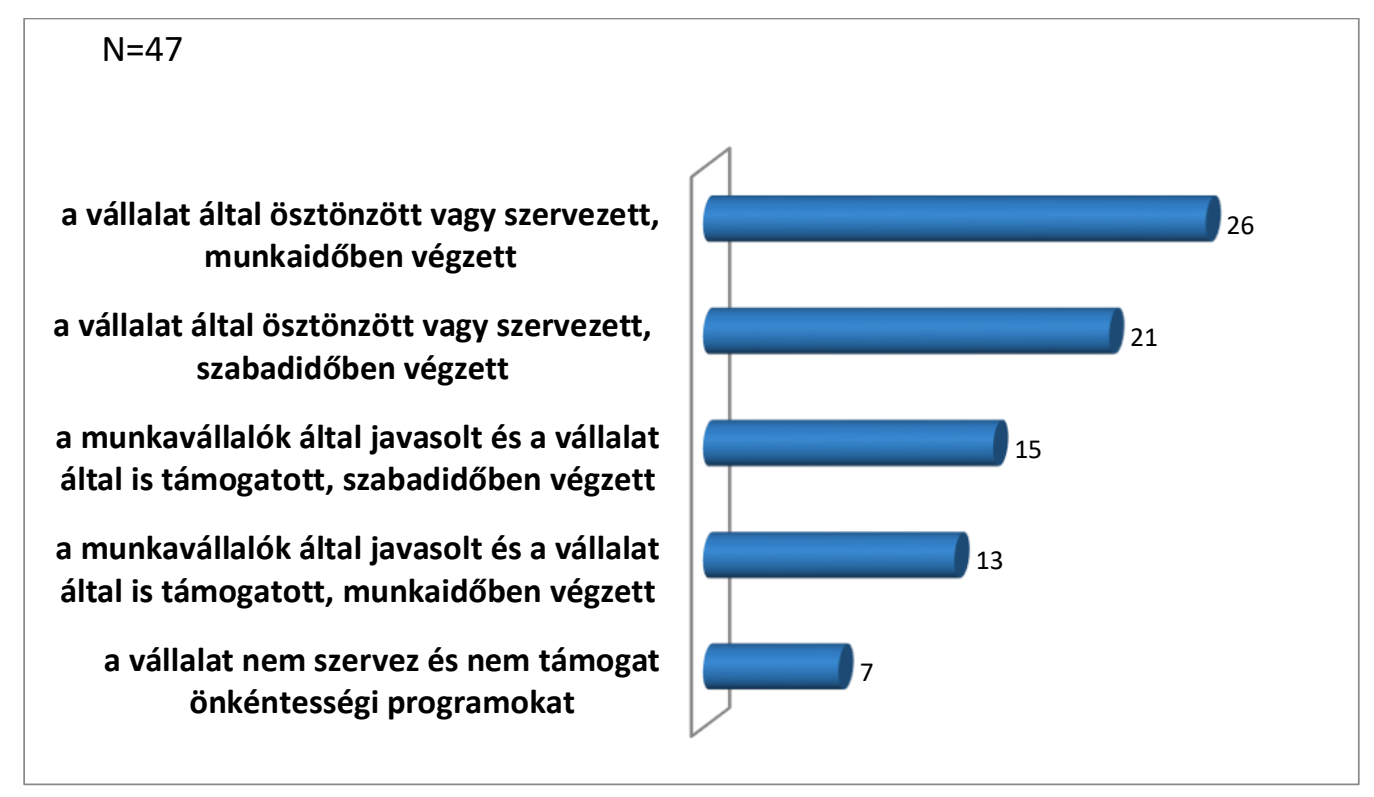

Forrás: Az Effekteam Egyesület 2015-ös kutatása 12.oldal 
A központi, illetve munkatársi kezdeményezések alakulásához az is hozzájárul, hogy számos cég számára dilemmát jelent, hogy noha a programokat nevében és tematikájában önkéntességnek nevezik, ugyanakkor aktívan és tevékenyen részt is vesznek azok szervezésében. Sok esetben kérdésként merül fel, hogy hol húzódnak a határok - az alulról vagy felülről jövő struktúrák - a kezdeményezések tekintetében. Ezért a vállalati szabályzatok, policyk - már amennyiben vannak - többször változnak a tekintetben, hogy például munkaidőben történjen-e az önkéntesség vagy sem; hogy a vállalat biztosítson-e anyagi erőforrásokat a kezdeményezésekhez vagy inkább ne; hogy elismerjék-e és/vagy jutalmazzáke az önkénteseket vagy ezt mellőzzék; illetve, hogy mennyiben legyenek központi, céges események vagy inkább a munkatársakra bízzák-e az önkéntesség megszervezését.

\section{MUNKAIDŐBEN VERSUS SZABADIDŐBEN VÉGZETT ÖNKÉNTESSÉG}

Általánosan elmondható, hogy a magyarországi cégeknél az elmúlt 10 évben egyre inkább jellemző, hogy munkaidőt biztosítanak az önkéntes tevékenységek megvalósításához, illetve, azt egyre több vállalat kompenzálja plusz szabadnappal, ha szabadidőben történik az önkéntesség.

Az Effekteam 2011-ben készített vizsgálatából még az látszott, hogy a vállalatok 61 százalékánál a munkatársak inkább szabadidőben végeztek önkéntes munkát (Effekteam Egyesület 2011:4). Ugyanakkor a 2015-ös felmérésünkből már az derült ki, hogy a megkérdezett vállalatok többségénél inkább a munkaidőben megengedett és támogatott önkéntesség volt az elterjedtebb (Effekteam Egyesület 2015:12).

Azon vállalatoknál, ahol a munkatársak szabadidőben engedélyezett önkéntes aktivitásairól a munkaidőben megvalósított aktivitásokra helyeződött át a hangsúly, jellemzően 1-4 munkanap időtartamot határoztak meg, ami az önkéntes munkával eltölthető munkaidőkeret. A munkaidőben való önkéntes tevékenységeknek megvan az az ösztönzője, hogy a vállalat már önmagában ezzel támogatja dolgozóját, hogy önkéntes munkát végezzen, azaz valami jót cselekedjen, illetve más tevékenységet csináljon, mint a megszokott munkaidőben. Ugyanakkor minden esetben, amikor a cég vált a szabadidőben való önkéntesség ösztönzéséről a munkaidőben való önkéntesség ösztönzésére, a középvezetők érzékenyítése és elkötelezetté tétele - a tapasztalatok szerint - elengedhetetlenné válik, hiszen 
munkaidőkeret ide vagy oda, csak olyan esetben tud egy-egy dolgozó önkéntes munkát vállalni, amikor és amennyiben a felettese elengedi.

Nyilvánvaló, hogy azoknál a cégeknél, ahol a vállalati önkéntesség munkaidőben (is) történik, szinte kivétel nélkül a HR rendszer részévé válik annak dokumentálása: konkrétan ki hány órát töltött el egy-egy év során azzal, hogy munkaidejében másoknak segít.

\section{FIZIKAI VERSUS SZELLEMI VAGY PRO BONO (SZAKMAI) ÖNKÉNTESSÉG}

A 2010-es évek elején szinte kizárólag a fizikai munka merült fel, mint lehetőség, ha a vállalatok az alkalmazottak önkéntes munkavégzésére gondoltak. Ahogy telt az idő, fokozatosan kapott teret a szellemi és/vagy pro bono önkéntesség is. Az Effekteam 2011-es felmérése szerint, amíg a cégek csupán 5 százalékánál volt jellemző ebben az időszakban kizárólagosan a szellemi önkéntes munka, addig 2015-ben ez az arány már 32 százalékra nőtt (Effekteam Egyesület 2015:14).

Ezt a növekedést már az Effekteam 2013-as kutatása is prognosztizálta, miszerint a cégek 53 százaléka nyilatkozott úgy, hogy a vállalati önkéntességen belül növekedni fog a munkatársak szakértelméhez kapcsolható feladatok aránya (Effekteam Egyesület 2013:13).

A hazai vállalatok a szellemi és a pro bono önkéntességet legtöbb esetben szinonimaként használják, ezért most a pontosság kedvéért teszünk egy rövid kitérőt a szellemi és pro bono önkéntesség megkülönböztetésére.

„A pro bono támogatások könnyen összetéveszthetők a szellemi, kompetencia alapú önkéntes munkával. A legfontosabb különbséget az jelenti a két támogatási forma között, hogy a pro bono tevékenységek alapvetően nem a munkavállalók, hanem a cég által vállalat önkéntes segítségnyújtását jelentik. A vállalat az alapszolgáltatását természetbeni támogatásként ajánlja fel valamilyen szervezetnek, de ugyanolyan feltételekkel, felelősségvállalással, és általában szerződés alapján, mint egyéb, üzleti ügyfeleinek. Leggyakrabban az üzleti szolgáltatásokat nyújtó vállalatoknál fordul elő ez a forma: pl. pénzügyi, jogi, IT vagy kommunikációs vállalkozásoknál." (Effekteam Egyesület 2015:14)

Sok esetben az, hogy egy vállalat alkalmazottjai fizikai vagy szellemi és/vagy pro bono önkéntes munkát végeznek, nemcsak a cégen múlik, hanem a munkavállalókon is.

„Az önkéntes feladatok jellegét tekintve a fizikai feladatok népszerűségének több oka is lehetséges. Egyrészt a tudás alapú, szellemi önkéntes feladatok általában rendszeres, 
hosszabb időn át tartó és jellemzően egyéni vagy legalábbis kis csoportban végezhető elkötelezettséget jelentenek. Ezzel szemben sok vállalatnál évente csak egy-két alkalommal nyílik munkaidőben végzett önkéntes feladatokra, valamint sok cég a nagyobb csoportban végezhető tevékenységeket preferálja. Másrészt hazánkban az amúgy is sok esetben irodai vagy szellemi munkát végző önkéntesek számára nagyobb élményt jelent az, ha a szokásos munkájuktól merőben eltérő feladatokat kapnak és kézzelfogható, maradandó eredményét láthatják a segítségnyújtásnak. Emellett még mindig kevés olyan társadalmi szervezetet vagy intézményt találhatunk, amely képes lenne rendszeresen önkénteseket fogadni és megfelelően foglalkozni velük, akár fizikai, akár szellemi munkáról van szó. Részben a szervezetek kis mérete miatt, illetve a legtöbb helyen kapacitáshiány miatt nem tudnak munkatársat biztosítani az önkéntesek koordinációjához, felkészítéséhez." (Effekteam Egyesület 2015:14)

Nem hagyható figyelmen kívül az a tényező sem, hogy a szellemi önkéntesség megvalósításához több odafigyelés, inkubáció, érzékenyítés szükséges a vállalat részéről, egyszóval több energia- és időbefektetést igényel, mint a fizikai önkéntes programok szervezése.

A szellemi és/vagy pro bono önkéntesség a nemzetközi témában jártas és elismert Taproot Foundation megállapítása szerint hatványozottan több, mintegy nyolcszoros értéket képes teremteni a fizikai önkéntességhez viszonyítva. Ehhez érdemes azt is hozzá tenni, hogy a szellemi és/vagy pro bono önkéntesség másfajta lehetőséget nyújt a munkatársak képességés készség fejlesztéséhez, mint a fizikai önkéntesség. Ugyanakkor, ahogy fentebb láttuk, a vállalatoknál az önkéntesség szervezésekor más célok (pl. reputáció, csapatépítés) nagyobb súllyal esnek latba, mint a munkatársak személyes, menedzsment vagy üzleti hatékonyságának fejlesztése. A szellemi és/vagy pro bono önkéntesség kisebb arányát talán ez a tény is befolyásolhatja.

A 2020-tól a vállalatok abba a helyzetbe kerültek, hogy a koronavírus-járvány következtében az év nagyobb részében ellehetetlenült a fizikai önkéntesség. Így több cég is nyitottá vált a szellemi és/vagy pro bono önkéntesség irányába. Ez újabb lökést adhat az önkéntesség ezen formájának, amit az Effekteam 2021-es kutatása is megerősített. Eszerint a következő időszakban a vállalatok 60 százaléka tervezi a szakmai és/vagy pro bono önkéntes tevékenységek ösztönzését, kipróbálását (7. ábra). 
7. ábra A következő évben (2021) Ön szerint várhatóan hogyan változik vállalatuknál az egyes támogatási típusok mértéke (a válaszadó 15 vállalat számában)

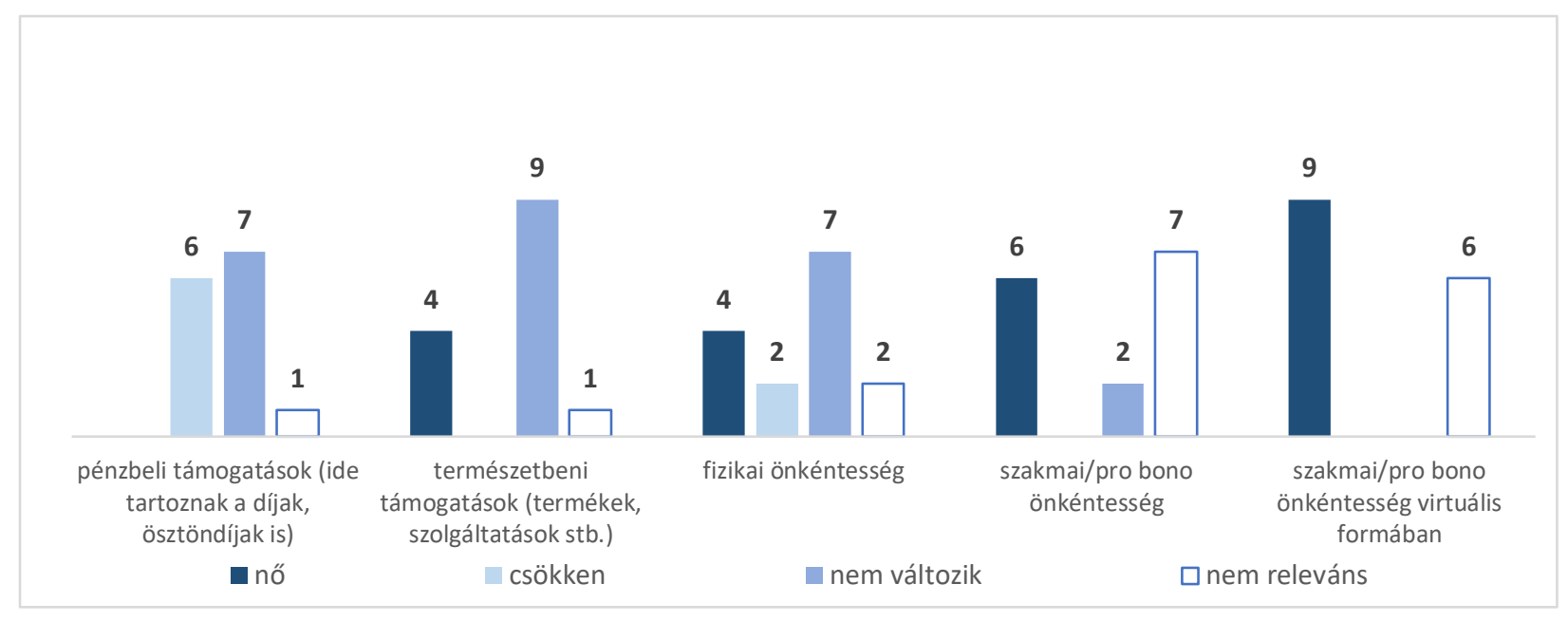

Forrás: Az Effekteam Egyesület 2021-es kutatása 7.oldal

\section{ESETI VAGY HOSSZÚ TÁVÚ ÖNKÉNTESSÉG}

A következő, 8. és 9. ábra alapján jól látható, hogy egyrészt az eseti önkéntes tevékenységek jóval népszerủbbek a hosszabb távú segítségnyújtásnál.

8. ábra Önkéntesség: eseti, egyszeri alkalommal történő segítségnyújtás, amely külön szakmai felkészülést nem igényel (a válaszadó vállalatok számában)

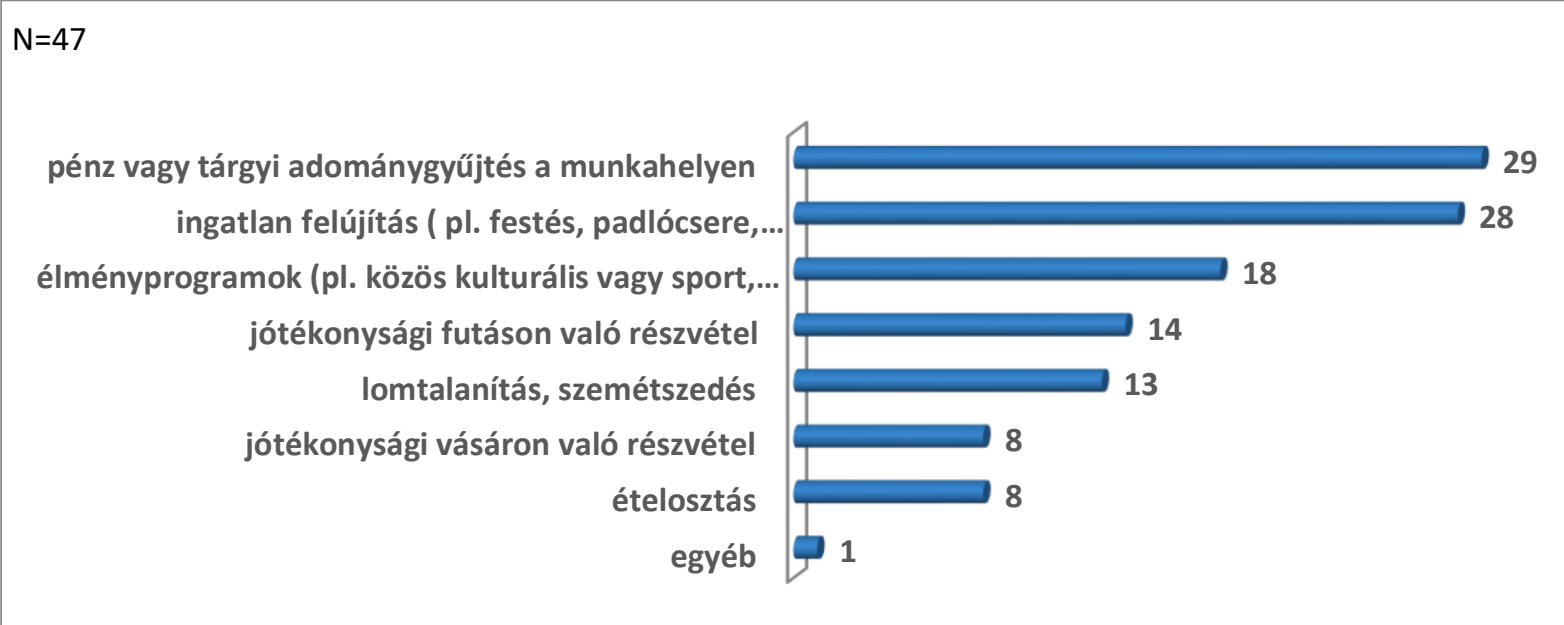

Forrás: Az Effekteam Egyesület 2015-ös kutatása 15.oldal

Másrészt az eseti segítségnyújtást jelentő feladatok között a legtöbb cég a munkahelyen történő pénzbeli vagy tárgyi adománygyújtést választja (29 említés), de emellett nagyon népszerűek a támogatott szervezet ingatlanjának a felújítását, megszépítését célzó tevékenységek is (28 említés). 
A hosszú távú, rendszeres együttmúködést kívánó programok között a véradás áll az első helyen (24 említés). Számos vállalat kifejezetten a munkahely területén ad erre lehetőséget.

9. ábra Önkéntesség: hosszú távú, rendszeres segítségnyújtás (a válaszadó vállalatok számában)

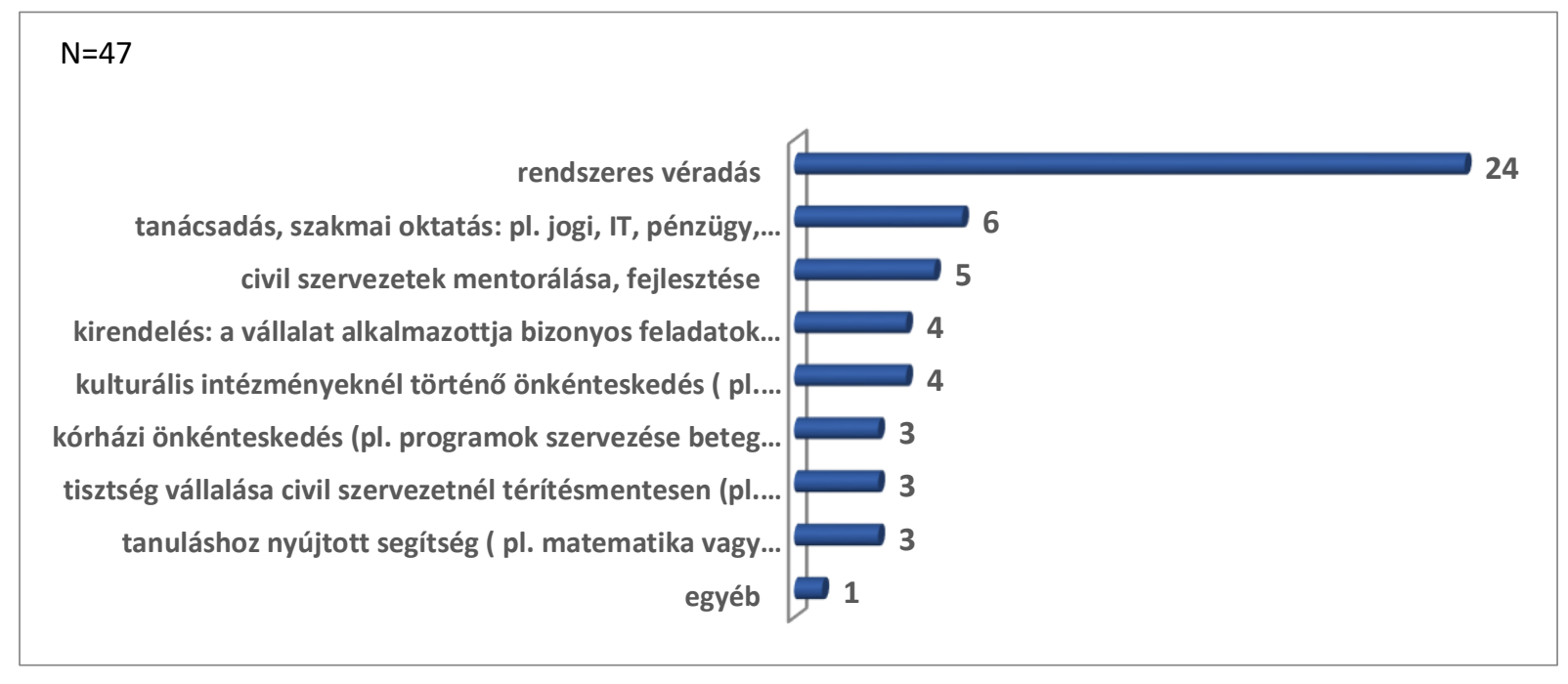

Forrás: Az Effekteam Egyesület 2015-ös kutatása 15.oldal

A főleg szellemi munkavégzéshez kapcsolódó, tartós elkötelezettséget kívánó feladatok még csak néhány cégnél fordultak elő, ezen tevékenységek említése jóval alacsonyabb (3-6 említés).

\section{CSOPORTOS VERSUS EGYÉNI ÖNKÉNTESSÉG}

A csoportosan végzett önkéntes tevékenységek a mai napig jóval népszerübbek a nagyvállalatok körében, mint az egyéni formában megvalósuló önkéntesség. Mind a vállalati önkéntesség céljainak meghatározása (például csapatépítés), mind a fizikai versus szellemi önkéntesség fejezetben részletezett okok - a fizikai önkéntesség előnyben részesítése - miatt választják a cégek munkatársai a mai napig is a csoportos formát az egyéni segítségnyújtással szemben. Míg az Effekteam 2011-es kutatása szerint a vállalatok 6 százaléka szervezett vagy támogatott kizárólag egyéni önkéntességet, addig 2015-ben ez az arány már 10 százalékos volt a megkérdezett vállalatok körében. 


\section{ÜGYEK, KEDVEZMÉNYEZETTEK}

Annak meghatározása, hogy egy-egy cég mennyire szúkíti le azon ügyek, kedvezményezettek és konkrét tevékenységek körét, amelyek a vállalati önkéntesség fókuszát jelentik, mindig stratégiai döntés kérdése. Ezen a téren az a legoptimálisabb, ha a vállalatok összehangolják a vállalati, a munkavállalói és a kedvezményezetti érdekeket.

Az Effekteam különböző időben végzett felvételeinek eredményei szerint az elmúlt 10 évben a legtöbb önkéntes órával megcélzott ügyek - ha változó arányban is - a környezetvédelem, az oktatás és a szociális ügyek voltak, amelyek a leginkább lehetővé teszik a felsorolt három vállalati, munkatársi és kedvezményezetti - érdekkör összehangoltságát.

Az Effekteam 2011-es kutatása alapján még leginkább a környezetvédelmet, a szociális területeket, valamint az oktatásügyet preferálták a vizsgálatban résztvevő cégek (Effekteam Egyesület 2011:10). A 2015-ös vizsgálatunk adatait érdemes megidézni ide, mert a támogatott tevékenységek sorrendje változott és a következőképpen alakult: az oktatásügy került az első helyre a legtöbbet említett ügyek közé, megelőzve a környezetvédelem és szociális területeket (10. ábra).

10. ábra Önkéntesség: milyen ügyeket támogatnak a vállalatok önkéntes programjaik során? (a válaszadó vállalatok számában)

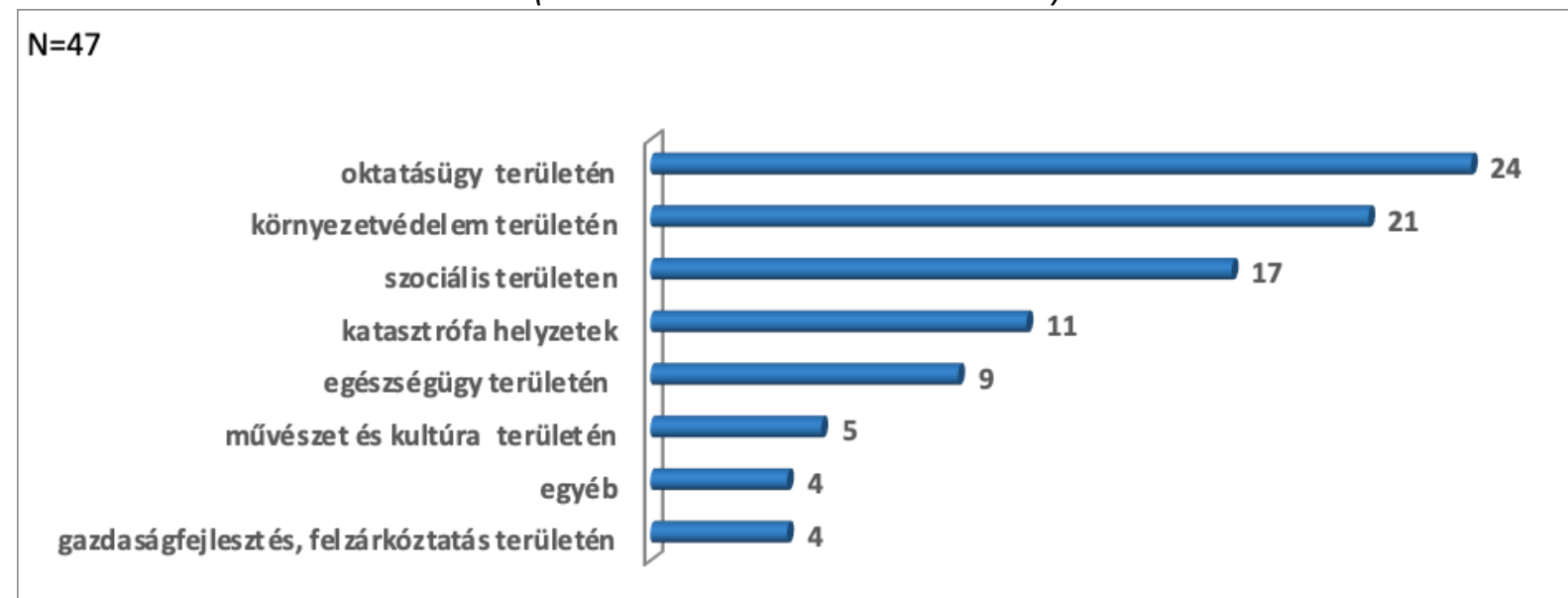

Forrás: Az Effekteam Egyesület 2015-ös kutatása 16.oldal

Az elmúlt tíz évben a kedvezményezetti kör tekintetében - sok vállalatnál a politikai, vallási szervezetek vagy fegyveres testületek önkéntes munkával való segítését kivéve - szinte bármilyen szervezet szóba jöhetett, legyen az alapítvány, egyesület, szociális szövetkezet, akár oktatási vagy egyéb önkormányzati intézmény. Az önkéntességgel való segítés esetén a 
kedvezményezetti kört tehát viszonylag tágan értelmezték a cégek, ugyanakkor érdemes felfigyelni arra, hogy az egészségügyi, valamint a múvészeti és kulturális területeket a válaszadók 19-11 százaléka említette, mint vállalati önkéntességgel támogatandó/támogatható „ügyet”.

\section{EREDMÉNYEK, HATÁSOK}

A társadalmi befektetések, ezen belül a vállalati önkéntesség nyomon követése - az eredmények és hatások feltérképezése, mérése - a mai napig gyerekcipőben jár még a nagyvállalati kört tekintve is. Következésképpen ezen a téren az elmúlt 10 évet tekintve nagy változások nem detektálhatóak. Pedig utánkövetés, mérés nélkül nagyon nehéz megmondani, vajon jó úton jár-e a cég, a kitűzött célok megvalósultak-e, illetve meg valósulnak-e.

A vállalati adatgyűjtés leginkább arra terjed ki, hogy hány munkatárs, hány munkaórában vett részt önkéntes aktivitásokban éves szinten. Sajnos rendszeres, átfogó kutatási eredmények sem állnak rendelkezése, hogy pontos számokról beszélhessünk.

$A z$, hogy az önkéntesség a vállalat üzleti működésére, valamint a munkavállalók életére hogyan hatott, milyen változásokat okozott - kevés kivétellel - szinte láthatatlan a cégek számára. Ezzel kapcsolatosan az Effekteam 2011-es kutatásából (Effekteam Egyesület 2011:14) az derült ki, hogy sok vállalat mindössze feltételezésekkel él arra nézve, hogy az önkéntes munkavégzés következtében javul a csapategység (71 százalékos említés), jobb lesz a munkahelyi hangulat (65 százalékos említés), illetve, hogy nő a vállalat reputációja (65 százalékos említés).

Több vállalatnál az a gyakorlat, hogy a cégek a munkatársaktól eseti élménybeszámolókat kérnek, vagy velük interjúkat készítenek, amelyeket a belső kommunikációs csatornákon publikálnak. Természetesen, ha a cég pénzbeni támogatást is ad egy-egy csapatnak az önkéntes munkavégzéshez, azzal szinte minden esetben tételesen el kell számolni az aktivitás megvalósítása után.

A későbbi, 2015-ös felmérésünk alapján már az látható, hogy a cégek a vállalati önkéntesség mérése és hatása esetében inkább a számszerúsíthető eredmény indikátorok (főként a résztvevők száma, média megjelenések száma, támogatott partnerek száma) figyelemmel kísérését helyezték előtérbe, mint a hatás indikátorokét (11. ábra). 
11. ábra Vállalatuknál milyen mutatók alapján követik, mérik a munkavállalók vállalati programokba való bevonásának eredményét és hatásait? (a válaszadó vállalatok számában)

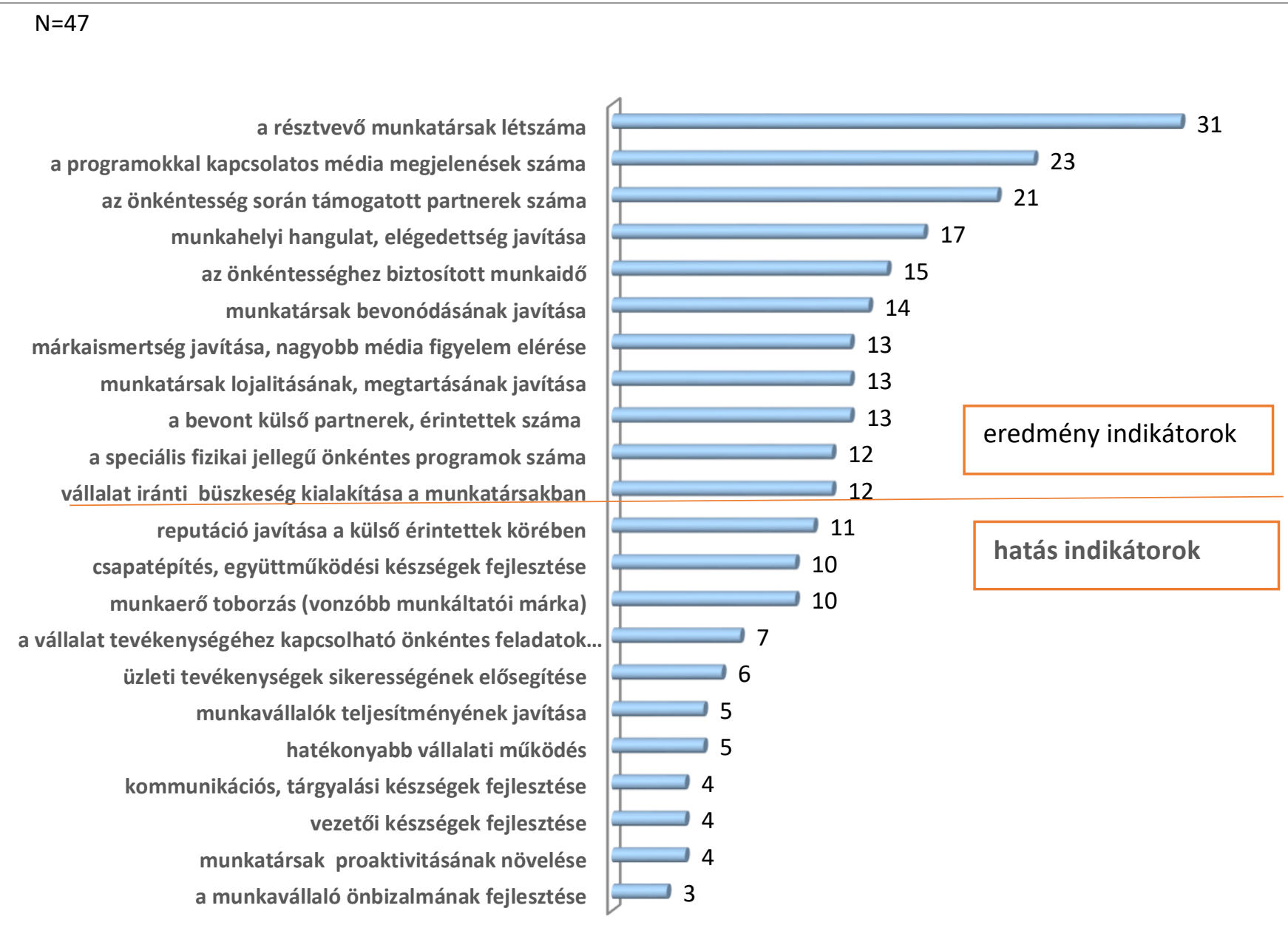

Forrás: Az Effekteam Egyesület 2015-ös kutatása 17.oldal

\section{ZÁRSZÓ}

Ahogy elemzésünk bemutatta, az elmúlt 10 évben az önkéntesség fokozatosan teret nyert a nagyvállalatok társadalmi felelősségvállalási gyakorlatában. Ugyanakkor, a mai napig úgy tekinthetünk rá, mint a cégek társadalmi befektetéseinek egyik legnagyobb potenciállal rendelkező formájára, amely még nem foglalta el az őt megillető helyét a hazai vállalatok gyakorlatában. A cégeknél rendszerint megvan a szándék arra, hogy növeljék ezen támogatások szerepét a társadalmi befektetések terén, ahogy ezt az Effekteam 2013-as és 2015-ös kutatásaiban felállított hosszú távú prognózisok is visszaigazolták.

Ugyanakkor több tényező is hátráltathatja ezen felelősségvállalási forma fejlődését, amelyek közül néhány mérvadó tényezőt ki kell emelni. Nehezítő tényezők közé sorolhatjuk a fogadó szervezetek hiányát, illetve azt a körülményt, hogy sok esetben külsős szakmai partner, 
szakmai támogatás nélkül nehéz megtalálni az önkéntesség „helyszínét”, legyen szó akár fizikai, akár szellemi önkéntességről. Ezenfelül az is tapasztalatható, hogy a vállalaton belüli fluktuáció miatt sok esetben elvész a vállalati felelősségvállalásról, így az önkéntesség menedzseléséről már megszerzett tapasztalat és tudás egy része, s így a cég kénytelen újra tanulni a már korábban bevett gyakorlatokat. Továbbá a vállalati önkéntesség fejlesztésének egyik akadálya a vezetői érzékenyítés vagy bevonás hiánya, hiszen az ő engedélyük nélkül csak törekvés marad a dolgozók számának növelése. Ezen túlmenően említést kell tenni az eredmény és hatásmérés hiányáról is, hiszen utánkövetés - eredmények és hatások feltérképezése és visszacsatolása - nélkül nehéz felmérni, hogy az önkéntességgel kitǔzött célok, mennyiben valósultak meg, és milyen irányokban érdemes tovább fejleszteni az önkéntes gyakorlatot.

Az elmúlt 10 évben több külső körülmény is katalizálta, illetve formálta ezen vállalati támogatási forma alakulását Magyarországon. Ezek közül az egyik legfontosabb volt, hogy a 2008-as gazdasági válságot követő években egy-egy vállalat, még ha nem is csökkentette éves szinten a társadalmi befektetéseinek összértékét, a három támogatási forma (pénzbeni támogatások, természetbeni támogatások, önkéntesség) közül a munkatársak munkaideje tűnt a legköltséghatékonyabbnak a pénzbeni vagy a természetbeni támogatásokkal szemben, ezért az önkéntesség aránya növekedni tudott a másik két támogatási formához képest. Következésképp ez a támogatási forma nagyobb hangsúlyt kapott a nagyvállalatoknál a felelősségvállalási aktivitásaik terén.

A válság ugyanakkor szemléletformálást is hozott abban a tekintetben, hogy a vállalatok társadalmi felelősségvállalási tevékenysége fókuszáltabbá, proaktívabbá vált. Ezenfelül a cégek támogatási stratégáját egyre inkább áthatotta az üzleti szemlélet, illetve az aktivitások menedzselése hatás- és eredményorientáltabbá vált, amely részint kihatott az önkéntességre is.

Ezen túlmenően az Európai Bizottság által 2011-ben meghirdetett Európai Önkéntesség Éve érezhetően lökést adott általában az önkéntesség, de a vállalati önkéntesség dinamikus növekedésének, társadalmi elfogadottságának. A 2011-es programok során az Európai Bizottság a vállalatok, a munkáltatók számára is deklaráltan értékessé kívánta tenni az önkéntességet, összhangban az európai alapértékekkel, a szolidaritás és a társadalmi kohézió erősítésével. 
A befolyásoló tényezők között mindenképp érdemes megemlíteni, hogy az önkéntesség a munkáltatói márkaépítés egyik eszközévé vált az elmúlt években. Ahogy az elemzésben láttuk, már az Effekteam 2015-ös kutatása is jelezte, hogy a cégek közel fele használja a támogatási programokat munkáltatói márkájának építéséhez. A 2010-es évek derekától pedig a munkaerő-piaci változások arra késztették a vállalatokat, hogy nagyobb figyelmet fordítsanak munkavállalóik személyes igényeire, preferenciáira, mint korábban. Ezért tudásalapon, hiteles felmérésekre, munkahelyi kutatásokra építve kell napjainkban kidolgozniuk azokat a megoldásokat, programokat, amelyek elősegítik a munkavállalók jóllétét, és a társaság iránti hosszú távú elköteleződését, amelynek része az önkéntesség is.

Végezetül azt sem hagyhatjuk figyelmen kívül, hogy a koronavírus-járvány ugyan átmenetileg, illetve időszakosan lehetetlenné tette a fizikai önkéntességet, ugyanakkor lehetőséget adott a cégek munkavállalóinak arra, hogy kipróbálják magukat a szellemi és/vagy pro bono önkéntesség terén. Ez az alkalom megfelelő alapot biztosíthat a jövőben ezen önkéntes forma beágyazódásának és terjedésének a hazai közegben is.

\section{IRODALOM}

Magyar Adományozói Fórum (2011): Vállalati önkéntesség (TOP200). Budapest https://effekteam.hu/wp-content/uploads/2019/06/vallalati_onkentesseg_2011.pdf Letöltve: 2021.11.10.

Magyar Adományozói Fórum (2012): Eseti támogatások a hazai vállalatok támogatási gyakorlatában 2012 (TOP 200+pénzügyi szektor). Budapest

https://effekteam.hu/wp-

content/uploads/2019/06/eseti_tamogatasok_a_hazai_nagyvallalatok_tamogatasi_gyakorlataban_2 012.pdf Letöltve: 2021.11.10.

Magyar Adományozói Fórum (2013): A hazai vállalatok társadalmi befektetéseinek trendjei 2009-2015 (TOP 200+pénzügyi szektor). Budapest

https://effekteam.hu/wp-content/uploads/2019/06/a-hazai_vallalatok_tarsadalmi-befekteteseinektrendjei-2009-2015.pdf Letöltve: 2021.11.10.

Magyar Adományozói Fórum (2015): A munkavállalók bevonásának szerepe a vállalatok támogatási programjaiban 2015 (TOP 200+pénzügyi szektor). Budapest

https://effekteam.hu/wp-

content/uploads/2019/06/a_munkavallalok_bevonasanak_szerepe_a_vallalatok_tamogatasi_progra mjaiban_2015tanulmany.pdf Letöltve: 2021.11.10.

Magyar Adományozói Fórum (2016): Vállalatok támogatási gyakorlata 2016 (TOP 200 és pénzügyi szektor). Budapest

https://effekteam.hu/wp-

content/uploads/2019/06/kutatasi_osszefoglalo_vallaltok_tamogatasi_tevekenysege_2016.pdf Letöltve: 2021.11.10. 
Effekteam Egyesület (2021): Társadalmi befektetések az Effekteam tagjainál - trendek 2021. Budapest https://effekteam.hu/wp-content/uploads/2021/03/Társadalmi-befektetések-az-Effekteamtagjain\%C3\%A1l-trendek-2021-1.pdf Letöltve: 2021.11.10. 